\title{
Incremental net benefits from the increasing in the production of koi fish Cyprinus carpio var. koi culture
}

\author{
Tambahan manfaat finansial peningkatan produksi budidaya ikan koi \\ Cyprinus carpio var. koi
}

\author{
Iis Diatin*, Dini F Nuristy, Ahmad Teduh, Muhammad Mujahid \\ Departemen Budidaya Perairan, Fakultas Perikanan dan Ilmu Kelautan, \\ Institut Pertanian Bogor, Kampus IPB Dramaga Bogor, Jawa Barat 16680 \\ *E-mail: iisdiatin@yahoo.co.id
}

\begin{abstract}
Koi fish is one of the species included in the intensification program of ornamental fish production. Production of koi has only reached $82.04 \%$ of total national production target thus making it potential for development. The objective of the study was to assess additional financial benefit of production increment through stocking pattern modification. Present research was performed using case study method on "Pokdakan PBC Fish Farm (PPFF)", koi fish farmers in Sukabumi. Financial analysis consisted of business analysis, investment criteria, and sensitivity. Stocking pattern management could increase ornamental fish production and its benefit margin up to 1.5 times higher. That investment criteria has shown net present value (NPV) at value of Rp3,824 million, net B/C ratio 4.96, internal rate of return (IRR) $86.0 \%$, and payback period (PP) 1.7 years. Koi fish farming was sensitive to a decline in survival rate and insensitive to the rise of formulated feed price.
\end{abstract}

Keywords: business analysis, koi, investment criteria, stocking pattern, production

\begin{abstract}
ABSTRAK
Ikan koi merupakan salah satu ikan yang termasuk dalam program penguatan produksi ikan hias Indonesia. Capaian dari target produksi ikan koi yang ditetapkan pemerintah hanya mencapai 82,04 \%, sehingga budidaya ikan koi potensial untuk dikembangkan dan ditingkatkan produksinya. Metode yang digunakan adalah studi kasus pada kelompok pembudidaya ikan hias koi "Pokdakan PBC Fish Farm (PPFF)" di Sukabumi. Analisis finansial yang digunakan meliputi analisis usaha, kriteria investasi dan sensitivitas. Pengaturan pola tebar dapat meningkatkan jumlah produksi ikan hias dan marjin keuntungan hingga 1,5 kali. Analisis kriteria investasi menghasilkan nilai internal rate of return (NPV) sebesar Rp3.824 juta, net B/C ratio 4,94, internal rate of return (IRR) 86,0\% dan payback period (PP) 1,7 tahun. Budidaya ikan koi sensitif terhadap penurunan kelangsungan hidup dan tidak sensitif terhadap peningkatan harga pakan buatan.
\end{abstract}

Kata kunci: analisis usaha, koi, kriteria investasi, pola tebar, produksi

\section{INTRODUCTION}

In Indonesia, ornamental fish has a high potential to develop, either freshwater or marine ornamental fish. Indonesia has 400 species out of 1,100 freshwater ornamental fish species traded globally, but only about 90 species that have been cultivated by the society (DJPB, 2015). Indonesian ornamental fish production in 2016 reached 1.9 billion individuals, while the production target for 2017 is 2.1 billion individuals. It indicates that the realization of the overall ornamental fish production has still reached $90.64 \%$ from the target (DJPB, 2016).

Koi fish is one of the fish included in the program to strengthen the production of ornamental fish in Indonesia in 2015-2019. The highest proportion in Indonesian ornamental fish production were generated from the production of koi fish that reached 36\% (DJPB, 2016). On the other hand, the percentage of koi fish production still reached $82.04 \%$ from the target set by the 
government, indicating that the koi fish farming is very potential to develope and improve. Koi fish production center in West Java is located in Sukabumi with the number of koi fish production in 2011 reaching 3.44 million individuals or equivalent with seven billion Rupiah, and in 2015 it experienced a sharp increase, reaching 21.88 million individuals or equivalent with 176 billion Rupiahs. The average increase in the production of koi fish in Sukabumi from 2011-2015 was $78 \% / y e a r$ (DKP, 2016). The demand of koi fish is more increasing along with the increasing in the number of the contest and the koi fish hobbyist community in Indonesia.

"Pokdakan PBC Fish Farm" (PPFF) is one of ornamental fish farmer groups in Sukabumi that cultivates koi fish as its primary commodity. The demand of koi fish to PPFF is quite high, but PPFF cannot fulfill all the demand. The demand of koi fish to PPFF can be fulfilled only $40 \%$, so there is available market opportunity to fulfill $60 \%$ unfulfilled demand. One of factors causing the low production of koi fish is the production period that has not been scheduled regularly and continuously. The effort to increase the production by maintaining the existing resources can be performed by regulating the production schedule. Production schedule that is set by setting the culture pattern or the stocking pattern can increase the production and keep the product continuity, so the product will always be available according to the customer demand. Based on these conditions, this study aimed to evaluate the incremental net benefit from the increasing in the production of koi fish by setting the stocking pattern.

\section{MATERIALS AND METHODS}

The observation method used was case study with the case unit of PPFF koi fish farmer community located at Cisaat, Sukabumi, West Java. This study was conducted on April-June 2016. The data collected consisted of primary and secondary data. The primary data were obtained from direct observation and interviews. Interviews were conducted with various parties including the chairman of PPFF, PPFF farmers and customers. Secondary data were obtained from literatures and documents in the fisheries companies, SI (Statistics Indonesia), MMAF RI (Ministry of Marine Affairs and Fisheries, Republic of Indonesia), and others. The analysis methods used in this study were the qualitative and the quantitative analysis. The quantitative analysis was operated to calculate the financial analysis, while the quantitative analysis performed consisted of tabulation and description.

The financial analysis included the business analysis and the investment criteria analysis. The business analysis included profit value and $\mathrm{R} / \mathrm{C}$ (revenue/cost) ratio, while the investment criteria analysis consisted of net present value (NPV), internal rate of return (IRR), net benefit/ cost (net $\mathrm{B} / \mathrm{C}$ ) ratio, payback period (PP) analysis and sensitivity analysis. The investment criteria analysis before the increasing of the production (without the stocking pattern) and after the increasing of the production (with the stocking pattern) were operated through the incremental net benefit method (Nurmalina et al., 2014).

The formulas used were as follows:

\section{Business analysis}

Profit $=$ total cost - total income

$\mathrm{R} / \mathrm{C}=$ total income $/$ total cost

\section{Investment criteria analysis}

NPV (net present value)

$\mathrm{NPV}=\sum_{(\mathrm{t}=1)}^{\mathrm{n}}\left[(\mathrm{Bt}-\mathrm{Ct}) /(1+\mathrm{i})^{\mathrm{t}}\right]$

Note:

$\mathrm{Bt}=$ benefits in year $\mathrm{t}$

$\mathrm{Ct}=$ costs in year $\mathrm{t}$

$\mathrm{t}=$ year of business

$\mathrm{i}=$ interest rate $(\%)$

$\mathrm{n}=$ business age

IRR (Internal rate of return)

$\mathrm{IRR}=\mathrm{i}_{1}+\left[\mathrm{NPV}_{1} /\left(\mathrm{NPV}-\mathrm{NPV}_{2}\right)\right] \times\left(\mathrm{i}_{2}-\mathrm{i}_{1}\right)$

Note:

i1 = discount rate resulting positive NPV

i2 = discount rate resulting negative NPV

$\mathrm{NPV} 1$ = positive NPV

NPV2 = negative NPV

Net $\mathrm{B} / \mathrm{C}$ ratio

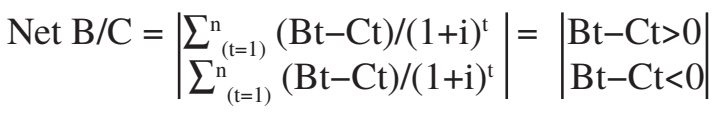

Note:

$\mathrm{Bt}=$ benefits in year $\mathrm{t}$

$\mathrm{Ct}=$ costs in year $\mathrm{t}$

$\mathrm{i}=$ interest rate $(\%)$

$\mathrm{t}=$ year 
Payback period (PP)

Payback period $=\mathrm{I} / \mathrm{Ab}$

Note:

I = investment cost

$\mathrm{Ab}=$ annual cash inflows

\section{Sensitivity analysis}

A sensitivity analysis using switching value method is a calculation method to assess the maximum change of a component that can be tolerated in order to keep the business still being feasible. In this study, changes analyzed were in the production input component (the rising of the feed price) and output component (the decreasing of the koi fish production).

\section{RESULTS AND DISCUSSION}

\section{The production and the marketing of koi fish}

The koi fish varieties cultured at PPFF were showa, kohaku, shiro, and sanke koi with a market size generally ranging from $20-25 \mathrm{~cm}$. The market opportunity based on the demand and the supply of koi fish at PPFF is presented in Table 1.

Table 1 shows that the demand for koi fish to this group was 7,000 individuals/month, and it could be filled only at a number of 2,800 individuals/month, it indicated that there were 4,200 individuals/month that could not be filled, it meant that there was a high market opportunity as many as 4,200 individuals/month (60\%). One of efforts to increase its production with keep maintaining the existing resources can be performed by regulating the production schedule. Production schedule set by the culture pattern or the stocking pattern could increase the production volume and also keep the product continuity to keep the product always being available according to the customer demand. The customers of koi fish at PPFF were middlemen sellers around Sukabumi, Bogor, and Bandung.

The schedule of one cycle of the koi fish culture conducted at PPFF, starting from the preparation of ponds, spawning, the rearing of larvae until harvested at a size of $20-25 \mathrm{~cm}$ required a period of six months. The koi fish culture production schedule at PPFF is presented in Table 2.

Before the stocking pattern set (before the production increasing) (Table 3), the harvesting was done every six months, but after the stocking pattern set (after the production increasing), the harvesting could be done every month. This led to an increase in the production number per year after the production increasing occured $(47,580$ individuals/year) reaching 1.5 -fold than before the production increasing occurred $(31,720$ individuals/year). This production increasing could increase the supply of PPFF to consumers at a number of 3965 individuals/month or equivalent with $94.4 \%$ the market opportunity fulfillment.

\section{Business analysis}

Costs spent to increase the production volume in koi fish farming business at PPFF consisted of

Table 1 . The data of the demand and the supply of koi fish with a size of $20-25 \mathrm{~cm}$ per month

\begin{tabular}{cccc}
\hline Customer & Demand (ind) & Supply (ind) & Market opportunity (ind) \\
\hline $\mathrm{Su}$ & 400 & 160 & 240 \\
$\mathrm{En}$ & 600 & 240 & 360 \\
$\mathrm{Nd}$ & 400 & 160 & 240 \\
$\mathrm{Om}$ & 400 & 160 & 240 \\
$\mathrm{Mu}$ & 1.200 & 480 & 720 \\
$\mathrm{Ma}$ & 800 & 320 & 480 \\
$\mathrm{M}$ & 400 & 160 & 240 \\
$\mathrm{Ay}$ & 1.200 & 480 & 720 \\
$\mathrm{Op}$ & 400 & 160 & 240 \\
$\mathrm{Er}$ & 400 & 160 & 240 \\
$\mathrm{Di}$ & 400 & 160 & 240 \\
$\mathrm{De}$ & 400 & 160 & 240 \\
\hline Total & 7,000 & 2,800 & 4,200 \\
\hline
\end{tabular}


Table 2. The koi fish culture production schedule before and after the production increment

\begin{tabular}{|c|c|c|c|c|c|c|c|c|c|c|c|c|c|c|c|c|c|c|c|c|c|c|c|c|c|}
\hline \multirow{2}{*}{ No } & \multirow{2}{*}{ Activities } & \multicolumn{4}{|c|}{ Month 1} & \multicolumn{4}{|c|}{ Month 2} & \multicolumn{4}{|c|}{ Month 3} & \multicolumn{4}{|c|}{ Month 4} & \multicolumn{4}{|c|}{ Month 5} & \multicolumn{4}{|c|}{ Month 6} \\
\hline & & 1 & 2 & 3 & 4 & 1 & 2 & 3 & 4 & 1 & 2 & 3 & 4 & 1 & 2 & 3 & 4 & 1 & 2 & 3 & 4 & 1 & 2 & 3 & 4 \\
\hline 1 & Preparation of ponds & & & & & & & & & & & & & & & & & & & & & & & & \\
\hline \multirow{4}{*}{2} & $\begin{array}{l}\text { Rearing of } \\
\text { broodstocks }\end{array}$ & & & & & & & & & & & & & & & & & & & & & & & & \\
\hline & Feeding & & & & & & & & & & & & & & & & & & & & & & & & \\
\hline & Water management & & & & & & & & & & & & & & & & & & & & & & & & \\
\hline & $\begin{array}{l}\text { Prevention of pests } \\
\text { and diseases }\end{array}$ & & & & & & & & & & & & & & & & & & & & & & & & \\
\hline \multirow{3}{*}{3} & $\begin{array}{l}\text { Broodstock } \\
\text { spawning }\end{array}$ & & & & & & & & & & & & & & & & & & & & & & & & \\
\hline & $\begin{array}{l}\text { Preparation of } \\
\text { broodstocks }\end{array}$ & & & & & & & & & & & & & & & & & & & & & & & & \\
\hline & $\begin{array}{l}\text { Injection of brood- } \\
\text { stocks }\end{array}$ & & & & & & & & & & & & & & & & & & & & & & & & \\
\hline 4 & Hatching of eggs & & & & & & & & & & & & & & & & & & & & & & & & \\
\hline \multirow{5}{*}{5} & Nursery I & & & & & & & & & & & & & & & & & & & & & & & & \\
\hline & Feeding & & & & & & & & & & & & & & & & & & & & & & & & \\
\hline & Water management & & & & & & & & & & & & & & & & & & & & & & & & \\
\hline & $\begin{array}{l}\text { Prevention of pests } \\
\text { and diseases }\end{array}$ & & & & & & & & & & & & & & & & & & & & & & & & \\
\hline & $\begin{array}{l}\text { Harvesting at a size } \\
\text { of } 5-7 \mathrm{~cm}\end{array}$ & & & & & & & & & & & & & & & & & & & & & & & & \\
\hline \multirow{5}{*}{6} & Nursery II & & & & & & & & & & & & & & & & & & & & & & & & \\
\hline & Feeding & & & & & & & & & & & & & & & & & & & & & & & & \\
\hline & Water management & & & & & & & & & & & & & & & & & & & & & & & & \\
\hline & $\begin{array}{l}\text { Prevention of pests } \\
\text { and diseases }\end{array}$ & & & & & & & & & & & & & & & & & & & & & & & & \\
\hline & $\begin{array}{l}\text { Harvesting at a size } \\
\text { of } 20-25 \mathrm{~cm}\end{array}$ & & & & & & & & & & & & & & & & & & & & & & & & \\
\hline
\end{tabular}

Table 3. The difference of the production number before and after the production increment of koi fish

\begin{tabular}{|c|c|c|}
\hline \multirow{2}{*}{ Parameter } & \multicolumn{2}{|c|}{ Production increment of koi fish } \\
\hline & Before & After \\
\hline The number of koi fish broodstock (set) & 8 & 8 \\
\hline Broodstock weight (kg) & 1.5 & 1.5 \\
\hline The number of eggs (eggs) & 18,000 & 18,000 \\
\hline Fertilization rate $(\%)$ & 80 & 80 \\
\hline Hatching rate $(\%)$ & 75 & 75 \\
\hline Survival in nursery $1(\%)$ & 80 & 80 \\
\hline Survival in nursery $2(\%)$ & 75.5 & 75.5 \\
\hline The production number/year (individuals) & 31,720 & 47,580 \\
\hline
\end{tabular}


investment costs, fixed costs and variable costs. The highest value change after the production increasing was found in the investment, because the additions of several primary facilities, including spawning ponds, broodstock ponds, nursery ponds, and production equipments, were required in the stocking pattern setting. The increasing of the production number led to an increase in revenue value that would ultimately add the profit (Table 4).

The profit value after the production increasing reached 1.5-fold higher than before the production increasing occured, it was also demonstrated on the higher value of revenue per cost $(\mathrm{R} / \mathrm{C})$ ratio and profit margin after the application of the stocking pattern. In the catfish culture, there was $\mathrm{R} / \mathrm{C}$ at a value of 2.28 (Diatin \& Dwirosyadha, 2009), the tilapia cultivation in hapa nets generated a profit margin at a value of $37.6 \%$, while those reared in the green house had profit margin at a value of $45.1 \%$ (Nasrallah et al., 2014). The stocking pattern setting was proven to be able to increase the profit margin with a high and different value in each grade. The profit margin obtained in koi fish grade A was two-fold higher, grade B was about 2.5 -fold higher and grade $\mathrm{C}$ was more than four-fold higher.

\section{Investment criteria analysis}

To calculate the long term financial benefits from the production increasing of this business, the investment criteria analysis has to be calculated. The calculation of the investment criteria analysis used these following assumptions:

1. The business age was ten years according to the most affected investment to the culture of koi fish (ponds).

2. Discount rate (i) used was society business credit or kredit usaha rakyat (SBC or KUR) from BRI in 2016 at a rate of 9\%/year.

3. The koi fish varieties harvested were showa, kohaku, shiro, and sanke koi sizing $20-25 \mathrm{~cm}$.

4. The time of one production cycle was six months, while the time needed for the rematuration of broodstocks was eight months.

5. The difference of the production volume before and after the production increasing is presented in Table 3.

Table 4. Business analysis before and after the production increment of koi fish

\begin{tabular}{lcc}
\hline & Parameter & \multicolumn{2}{c}{ Production increment of koi fish } \\
\cline { 2 - 3 } & Before & After \\
\hline Investment cost (Rp) & $586,126,000$ & $942,696,000$ \\
Fixed cost (Rp) & $155,423,900$ & $190,382,600$ \\
Variable cost (Rp) & $208,115,200$ & $308,372,500$ \\
Total cost (Rp) & $363,539,100$ & $498,755,100$ \\
Revenue (Rp) & $951,600,000$ & $1,459,944,000$ \\
Profit (Rp) & $588,060,900$ & $761,188,900$ \\
R/C & 2.62 & 2.93 \\
Profit margin (\%) & & \\
Grade A & 60.54 & 125.52 \\
\multicolumn{1}{c}{ B } & 37.60 & 95.87 \\
\multicolumn{1}{c}{ C } & 14.67 & 63.22 \\
\hline
\end{tabular}

Table 5. The investment criteria analysis in the koi fish culture

\begin{tabular}{lccc}
\hline \multicolumn{1}{c}{ Investment criteria } & Unit & Feasibility & Result \\
\hline NPV (net present value) & Rp & $>0$ & $3,823,821,676$ \\
Net B/C (benefit/cost) & & $\geq 1$ & 4.94 \\
IRR (internal rate of return) & $\%$ & $>$ i & 86.0 \\
PP (payback period) & year & $<$ business age & 1.7 \\
\hline
\end{tabular}


6. The percentages of koi fish from several grades in one production cycle were $20 \%$ grade A, $60 \%$ grade $\mathrm{B}$, and $20 \%$ grade $\mathrm{C}$.

7. The selling prices of each koi fish grade were Rp35,000/individual for grade A, Rp30,000/ individual for grade $\mathrm{B}$, and $\mathrm{Rp} 25,000 /$ individual for grade $\mathrm{C}$.

The results of the investment criteria analysis calculation in the koi fish culture at PPFF is in Table 5. Based on the calculation results through incremental net benefit method, it could be known that net present value (NPV) obtained by the koi fish farmers after the production increasing occured through the stocking pattern setting was Rp3,823,821,676. This NPV could be increased through the increasing of output values such as the production volume and the selling price, it could also be increased through the input use efficiencies such as feed etc. The results from the study by Poot-Lopez et al. (2014) demonstrated that tilapia fed through feeding rate method resulted NPV that was 1.5 to 3 -fold higher than those fed through at satiation method. The catfish Pangasius sp. cultured in recirculation system resulted a higher production volume and NPV that was two-fold higher than those cultured in traditional system (Ngoc et al., 2016). The culture of scallop Clamys farreri and seaweed Laminaria japonica with integrated multi trophic aquaculture (IMTA) system resulted NPV that was 1.5 to 2-fold higher than monoculture system (Yu et al., 2017). Benefit and cost ratio (net B/C) obtained in this study was 4.94 that indicated every one Rupiah of cost spent would obtain benefit at a value of Rp4.94 during its business age that was ten years. The IRR value of $86.0 \%$ indicated that PPFF got a return at a rate of $86.0 \%$. The investment that was invested in the koi fish culture business would be returned after 1.7 years or one year and eight months.

Several previous studies, ie. on goldfish Carassius auratus demonstrated a net B/C of 1.12, an IRR of $42 \%$ and a PP of 1.72 years, platyfish Xiphophorus maculates had a net B/C of 1.20 , an IRR of $26 \%$ and a PP of 2.46 years, while manfish Pterophyllum scalare resulted a net B/C of 1.22 , an IRR of $27 \%$ and a PP of 2.39 years (Mandal et al., 2007). Moreover, the culture of the consumption fish in India resulted a net B/C of 1.35 and an IRR of 53\% (Das et al., 2013). The culture of the freshwater prawn Macrobrachium amazonicum obtained a net B/C value of 3.9, an IRR of $48 \%$, and a PP of 2.4 years (Valenti et al., 2011), Pacific white shrimp Litopenaeus vannamei obtained NPV at a value of Rp7.2 billion, a net B/C of 2.62 and an IRR of $47.84 \%$ (Diatin \& Kusumawardany, 2010) and lobster Panulirus ornatus resulted a net $\mathrm{B} / \mathrm{C}$ value of 1.44 (Petersen \& Phuong, 2010).

The culture of common carp Cyprinus carpio reared in ponds resulted a net $\mathrm{B} / \mathrm{C}$ of 1.03 and an IRR of $12.67 \%$ (Khan \& Manzoor, 2014). The culture of catfish Clarias gariepinus obtained a net $\mathrm{B} / \mathrm{C}$ value of 1.69 (Olaoye et al., 2013), and a net $B / C$ of 1.001 and an IRR of $10 \%$ under normal conditions, then there was an increase in net $\mathrm{B} / \mathrm{C}$ to be 1.34 and IRR to be $23 \%$ with the presence of incentives in the form of additional funds (Sara et al., 2014). A financial analysis in the culture of tilapia Oreochromis niloticus showed a net $\mathrm{B} / \mathrm{C}$ value of 1.48 and an IRR of $95 \%$ (Afolabi et al., 2012), a net B/C of 1.05 and an IRR of $11 \%$ under normal conditions and if that got additional incentive funds resulted an increase in net B/C to be 3.97 and an IRR to be $29 \%$ (Sara et al., 2014). Tilapia reared in aquaponic system resulted an IRR of $7.36 \%$ with a sales proportion of $21 \%$ tilapia and $79 \%$ vegetables (Tokunaga et al., 2015).

If compared with the calculation results in this study, the values obtained were relatively higher, it indicated that the stocking pattern setting could increase the production volume that ultimately improved the financial performance of this cultivation business. According to Young et al. (2015) the increase in the business scale characterized by an increase in the production volume can increase the profit almost tripled of it.

\section{Sensitivity analysis}

The calculation of sensitivity analysis (Table 6) was used to see the percentages of changes in the production factors and the costs that made the business reached a feasibility point. The components used in this analysis were the decrease in the koi fish production and the rising of the feed price.

The unfeasibility points of the koi fish culture business were in the decrease in the production at a value of $36.70 \%$ and the rising of the feed price at a value of $109.96 \%$. If there was a decrease in the production more than $36.70 \%$ or a decrease in survival (SR) up to $48.43 \%$, so the business was not feasible to be conducted. If there was the rising of the feed price more than $109.96 \%$ or the rising of the feed price up to Rp16.00-167.00/kg, so the business had not been feasible to be conducted. The results of the sensitiviy analysis reported by 
Valenti et al. (2011) showed a business would not be feasible to be conducted, if there was a decrease in the selling price of tilapia at a value of $44 \%$ and the rising of the artificial feed price at a value of $90 \%$, while according to Tokunaga et al. (2015) the rising of the artificial feed cost at a value of $1 \%$, increased the operational cost at a value of $0.13 \%$. Based on the results of the sensitivity analysis obtained in Table 6 , so it could be concluded that the koi fish culture business at PPFF was sensitive to a change in survival and was not sensitive to a change in the feed price.

\section{CONCLUSION}

The production increasing of the koi fish culture through the stocking pattern setting could add financial benefits and was feasible to be developed. This business was sensitive to a decrease in survival and was not sensitive to the rising of the feed price.

\section{ACKNOWLEDGEMENTS}

The authors are grateful to Ministry of Research, Technology and Higher Education for funding this research. Special gratitude is also given to the Laboratory of Environment, Department of Aquaculture, Bogor Agricultural University for providing facilities during research.

\section{REFERENCES}

Afolabi JA, Imondu PB, Fagbenro OA. 2012. Economic and technical viability of tilapia culture in homestead concrete tanks in peri-urban Nigeria. Advanced Research in Economic and Management Sciences 5: 228-237.

Das A, Kumar NR, Krishnan M, Yadav VK. 2013. Economic viability of aqua-model village scheme: a case study in West Tripura District. Indian Journal of Fisheries 60: 41-46.

Diatin I, Dwirosyadha, GA. 2009. Analisis finansial penggunaan lampu petromak sebagai pemanas pada budidaya pembenihan ikan patin. Jurnal Kebijakan dan Riset Sosial ekonomi Kelautan dan Perikanan 4: 121-239.

Diatin I, Kusumawardany U. 2010. Financial analysis of pond area extension in Pacific white shrimp culture at Cantigi Indramayu. Jurnal Akuakultur Indonesia 9: 77-83.

[DJPB] Direktorat Jendral Perikanan Budidaya. 2015. Laporan kinerja triwulan II tahun
2015. Jakarta: Direktorat Jendral Perikanan Budidaya. Kementerian Kelautan dan Perikanan.

[DJPB] Direktorat Jendral Perikanan Budidaya. 2016. Realisasi dan capaian anggaran tahun 2016. Jakarta: Direktorat Jendral Perikanan Budidaya.

[DKP] Dinas Kelautan dan Perikanan Kabupaten Sukabumi. 2016. Laporan statistik produksi budidaya ikan hias dan nilai menurut jenis ikan tahun 2011-2015 di Kabupaten Sukabumi. Sukabumi. Dinas Kelautan dan Perikanan.

Khan SB, Manzoor SR. 2014. Viability of carp fish farming: a case study of KP, Pakistan. City University Research Journal 4: 131-146.

Mandal S, Mahapatra BK, Tripathi AK, Verma MR, Datta KK, Ngachan SV. 2007. Agribusiness opportunities of ornamental fisheries in North-Eastern region of India. Agricultural Economics Research Review 20: 471-488.

Nasrallah AM, Dickson MW, Al-Kenawy DAR, Ahmed MFM, El-Naggar GO. 2014. Technical characteristics and economic performance of commercial nilapia hatcheries applying different management systems in Egypt. Aquaculture 426-427: 222-230.

Ngoc PTA, Meuwissen J, Tru LC, Bosma RH, Verreth J, Lansink AO. 2016. Economic feasibility of resirculating aquaculture systems in pangasius farming. Aquaculture Economics \& Management 20: 185-200.

Nurmalina R, Sarianti T, Karyadi A. 2014. Studi Kelayakan Usaha. Bogor. PT. Penerbit IPB Press.

Olaoye OJ, Ashley-Dejo SS, Fakoya EO, Ikeweinwe NB, Alegbeleye WO, Ashaolu FO, Adelaja OA. 2013. Assesment of socioeconomis analysis of fish farming in Oyo State, Nigeria. Global Journal of Science Frontier Research Agriculture and Veterinary 13: 45-55.

Petersen EH, Phuong TH. 2010. Tropical spiny lobster Panulirus ornatus farming in Vietnam, bioeconomics and perceived constraints to development. Aquaculture Research 41: e634-e642.

Proof-Lopez GR, Hernandez JM, Gasca-Leyca E. 2014. Analysis of ration size nile tilapia production: Economics and environmental implications. Aquaculture 420-421: 198-205.

Sara RR, Ismail MM, Kamarulzaman NH, Mohamed ZA. 2014. The impact of government incentives on financial viability 
of selected aquaculture species in Malaysia. International Food Research Journal 21: 1451-1456.

Tokunaga K, Tamaru C, Ako H, Leung PS. 2015. Economics of small scale commercial aquaponics in Hawai'i. Journal of The World Aquaculture Society 46: 20-32.

Valenti WC, Hayd LA, Vetorelli MP, Martins MIEG. 2011. Economic analysis of Amazon river prawn farming to the markets for live bait and juveniles in Pantanal, Brazil. Boletim
Do Instituto De Pesca 37: 165-176.

Young BCC, Yeh S, Cheng W, Lee P, Chung RH. 2015. The status of aquaculture operations and cost analysis in Honduras tilapia industry. Global Science Research Journal 3: 257-264. Yu LQJ, Mu Y, Zhao Z, Lam VWY, Sumaila R. 2017. Economics challenges to the generalizationof integrated multi-trophic aquaculture: An empirical comparative study on kelp monoculture and kelp-mollusk in Weihai, China. Aquaculture 471: 130-139. 